\title{
Ancient Structures of West Moana: Observing the Tombs, Mounds and Forts
}

\section{Abstract:}

This paper will observe three ancient structures of Western Oceania and analyze their social significance and historic impacts on the native civilizations therein, alongside their relationships with each other among Western Moana cultures. Additionally, this paper will focus primarily on the early kingdoms of Tonga, Sāmoa, Wallis and Futuna; exploring the native land structures of the Star Mounds and Pulemelei mound of Sāmoa, Fort Talietumu in 'Uvea (Wallis) and royal burial tombs of the Tu'i Tonga in Lapaha, Tongatapu. As researchers who have genealogical links to these sights, we tell this story.

Elijah Lemusuifeauaali'i (Matāutu Lefaga, Malie, Eva, Ngāti Porou, Te Whanau a Apanui $\&$ Te Whanau a Maruhaeremuri) is an undergraduate student majoring in Pacific Island Studies and Cultural Anthropology at Brigham Young University of Hawaii.

Dion Enari (Lepa, Malaela, Safune, Vaiala, Nofoali'i) is a Samoan PhD candidate in the Faculty of Society and Design, Bond University, Gold Coast, Australia. 


\section{Introduction}

Migration is not a new or foreign phenomenon for the Oceanic region (Hau'ofa, 1994). Moana, a term for Pacific cultures reemphasized by Tevita $O$. Ka'ili, refers to the people and cultures of the South Pacific in a more culturally correct and appropriate way (Ka'ili, 2005). Considering that term, Moana cultures have practiced the art of migration for centuries in both attempt and ambition to seek new resources, improve lifestyles, diversify social relations and expand imperial boundaries (Enari \& Matapo, 2020; Enari \& Matapo, 2021). Among the diverse groups in Western Oceania, the indigenous clans of Tonga, Sāmoa and Fiji were perhaps the most entrepreneurial in their pursuits to expand their dominion whether through means of trade, war or matrimony (Gunson, 1997). Many aspects of social and indigenous culture such as language, cultural custom, protocol and characteristics of ancestry are still evident among these Moana cultures today as a result of these early endeavors (Chao \& Enari, 2021; Lemusuifeauaali'i $\&$ Enari, 2021). However, over time certain origins and histories have gradually been forgotten and regarded as common tradition, when in fact they are a unique mix of ancient interactions and implementation (Radakovich, 2004). Shankar Aswani and Michael Graves write in regard to the maritime expansion of Tonga, that "Environmental and geographical conditions played a critical role in the development of Tongan social stratification and expansionist strategies, including voyaging, trade, and warfare" (Aswani \& Graves, 1998).

Tonga is the only Moana kingdom to have not been overruled by a foreign power, it has been classified as one of the most successful kingdoms in the West Moana with 
regard to maritime expansionism. Between 1200AD to 1500AD, Tonga was at the height of their expansion with the $10^{\text {th }}$ king, Tu'i Tonga Momo (Campbell, 1947) leading forward the evolution of Tonga. "Tongan ruling elites encouraged younger collaterals to wage warfare on other islands and thus redirected their rivalry away from themselves and against other groups, while at the same time furthering territorial expansion through the incorporation (at varying levels) of independent chiefdoms. Tongans were able to consolidate their power internally and redirect potential rivals through three major strategies: (1) by establishing new aristocratic titles, (2) by encouraging younger siblings or individuals from junior lines to engage in expansionist warfare, and (3) by controlling the development and use of voyaging technology and lore so as to effectively transport staple goods and to monopolize their position for the transport of wealth finance and the institutionalized exchange of high-ranking spouses" (Aswani \& Graves, 1998, p.140). Whilst Sāmoa was also active in their maritime chiefdom, particularly throughout parts of the Cook Islands and Hawai'i, Tonga maintained strong influences in varying Moana regions in east 'Uvea, Rotuma, Futuna, Sāmoa, Niue, parts of Micronesia (Kiribati, Pohnpei), Vanuatu and New Caledonia and the Loyalty Islands (Geraghty, 1994).

With the expansion of the Tongan empire, Tongan royals often travelled abroad to other islands intermixing with neighboring Moana cultures. Her Majesty, Queen Sālote and Adrienne Kaeppler both mention particular Tongans in Moana history with Sāmoan counterparts and relatives (Bott, 1982;Kaeppler, 1978). Among various Tongan scholarship, Dr. 'Ōkusitino Māhina provides an account 
of the first king of Tonga's origin story [King 'Aho'eitu or Tu'i Tonga 'Aho'eitu], and how Tu'i Tonga 'Aho'eitu shared Sāmoan links via his father [Tagaloa 'Eitumatupu'a] and Tongan links through his mother ['Ilaheva Va'epopua] (Faka'osi, 1993). Interestingly, if we consider this possibility in dual lineage, it presents Sāmoa as a potential ancestral homeland for the Tu'i Tonga dynasty. As Māhina further explains, Tagaloa 'Eitumatupu'a resided in the Langi [sky/ heavens] (Māhina, 1992), additionally highlighting the possible Godly bloodline shared through 'Aho'eitu's patriarchal line. This also places Sāmoa, more emphatically the Manu'a islands as an integral, sacred and common residence by early Tongan kings (Tuimalealiifano, 2006). With Tongans taking up residence (900-1200AD) in Sāmoa and maintaining numerous forms of socio-cultural intersection, the later introduction of the Mālietoa title initiated a genesis to the departure, defeat and expulsions of Tongans in Sāmoa (Tuimalealiifano, 2006). This new era that aimed to eliminate Tongan influence in Sāmoa limited the extent of control between Sāmoan and Tongan borders, launching new priorities of national management in the everyday decisions of the empires. It is important to note however, that the reign of varying Tongan kings in Sāmoan history are more than one (Tuimalealiifano, 2006). However, as Gunson and Tuimaleali'ifano point out, despite Tongan expulsion, those who were successful of the The Tu'i Tonga line, later returned to Sāmoa or Manu'a claiming Sāmoan identity to reside with their assumed high born Sāmoan wives, while the Tu'i Ha'atakalaua line took over as secondary authority in central Tonga (Gunson, 1987; Tuimalealiifano, 2006). 


\section{Star Mounds of Pulemelei, Savai'i Sāmoa}

The word Sāmoa can be defined in two words, 'Sā - Moa', meaning 'Sā' sacred and 'Moa' center, the sacred center or as it is often referred to as the heart of Polynesia. (Rottman, 2002). Before the arrival of colonial rule, Tonga, Fiji and Sāmoa held their own respected royal dynasties that had been significantly active in the West Pacific exploration and growth expeditions, often engaging in intermarriage as a means for cultural and political expansion (Barnes \& Hunt, 2005). The Fijian empire has been known as TuiFiti or Tui Fiti, following after the Sāmoan translation, similar to its native title 'Viti'. Tonga, had already been established as the Tu'i Tonga, being also the first of three primary royal Tongan lines. Sāmoa, named Tui Manu'a, after the island of Manu'a to which is currently recognized under American Sāmoa. The neighboring independent nation of Sāmoa, west of American Sāmoa consists of two large islands Savai'i and Upolu, with eight smaller islands. These islands are volcanic with rocky and rugged mountains found in the interior, surrounded by lush tropical forests and abundantly inhabited coastal plains (Rapaport, 2013). Many of the residents in independent Sāmoa have settled on coastlines (Martinsson-Wallin, 2007), including the capital city of Apia.

Sāmoa and American Sāmoa have numerous archeological remains from what anthropologists and other scholarship have called star mounds, with a growing number particularly in American Sāmoa (Herdrich, 1991). The Palauli cultural heritage trail, situated in the village of Vaito'omuli, Palauli on the island of Savai'i is one of the largest mound sites in Sāmoa. It reveals much of an ancient megalithic civilization that 
once ruled over ancient Sāmoa, as recorded by Wallin, Martinsson-Wallin and Clark. Western Polynesians began to migrate eastward, this is evidenced in the monumental and complex architecture (Wallin, et al., 2007). Archeologist and Anthropologist Gregory Jackmond explains via TV interview that the Pulemelei mound is not a star mound but rather a mound as its current terminology, although some observers have called it a temple, Jackmond goes on to explain that the Pulemelei mound is 60 meters long on all sides, 12 meters tall and made up of two flat stone levels almost resembling a set of stairs. Overall, it is the largest stone platform in the South Pacific. Although the star mounds themselves are much smaller in size and more scattered, it is speculated they serve a differing purpose. Wallin, et al (2007) show the radiocarbon data revealing the time and material makeup of the Pulemelei mound is of volcanic rock dating back as early as 200AD - 700AD and as late as $1700 \mathrm{AD}$. However, it is important to note that this research also exhibits an assortment of timeframes, in that some sections and perhaps areas of the Pulemelei mound may be older or younger than others, presumably due to the time required for construction. (Wallin,et al., 2007). Research on the accuracy of dates is still ongoing. "The Pulemelei Mound is a monumental stone mound with a volume of $17,000 \mathrm{~m} 3$, surrounded by more than 1,000 smaller stone platforms, indicating it held an important position in the settlement hierarchy " (Clark, et al., 2014, p.251). In addition to the Pulemelei mound or perceived temple, there are also a number of other sites referred to as star mounds, named for their interesting star-like shape. Recorded with mounds both built above 
the surface and into the earth ranging from 3 meters high and deep.

"The excavations recovered charcoal from all pits and the trench. Fragments and dispersed charcoal were frequently found at of about $20 \mathrm{~cm}$ to $40 \mathrm{~cm}$ below the ground surface. It is possible that the charcoal represents initial clearing and burning during the building phase or post construction vegetation clearance. In one of the test pits as well a in the larger trench (Trench 1), we found prehistoric earth ovens (umu) at the same depth as the scattered charcoal and Test Pit 3 also contained a charcoal concentration" (Wallin, et al., 2003).

Furthermore, excavation on the Pulemelei mound shows a perceived early civilization with radiocarbon dates that "suggest that activities in the vicinity of the [Pulemelei] mound span 620AD to 1690AD, although the presence of a few ceramic sherds might indicate human use before AD 600" (Wallin, et al., 2003).

Locals of the Vaito'omuli village and Palauli district believe that the star mounds were areas in which elders and chiefs would hold ceremonial meetings and customs. Chief of Vaito'omuli village, Leituala Filipo Leituala in an interview with the New Zealand TV program Tagata Pasifika, shared his beliefs on the matter commenting that "the primary use of the star mounds, were for the use of pigeon snaring" (Coconet TV, 2019). A similar practice that was also evident in early Tonga, regarded by both groups as a sport for royals to indicate their wealth and status (Burley, 1996). However, Jackmond disagrees with this theory as star mounds are not evident in Tonga (Coconet TV, 2019).

Over time, the mound has gradually been covered by tropical growth and slowly abandoned. Local inhabitants 
themselves were unaware and had never known of its exact location nor history due to lack of oral records and vegetation overgrowth (Code, et al., 2020). The mound project by Anthropologists and Archeologists Gregory Jackmond and Dione Fonoti, has allowed for new discussion, questions and understanding on the heritage that lays beneath the feet of Sāmoans. Laser technology has revealed that the expanse of the initial mounds is in reality monumental, suggesting that rather than individual separate mounds, perhaps in actuality there is a range of settlements proposing there was in fact an ancient civilization (Code $\&$ Cavanagh, 2020).

\section{Fort Talietumu, 'Uvea}

Situated on the island of 'Uvea (Wallis) and Futuna, is the large volcanic rock settlement of Talietumu. Positioned in the heart of the island of 'Uvea (Wallis) northeast of the village Halalo in the district of Mu'a, Talietumu sits hidden amongst the dense tropical forest of the island. Locals of 'Uvea believe the settlement was once a fortress built and belonging to ancient war parties and warlords of the Tu'i Tonga empire, perhaps also where Tongan title holders were buried. Built from basalt rock and surrounded by numerous defensive walls estimated to be once 3 meters high, with an elevated point in the middle of the site (Clark \& Martinsson-Wallin, 2007). Archaeologist Christophe Sand (2006) believes, that Talietumu is a mound that lays within the greater fort barrier of what is called 'Kolonui', and describes that the architectural construction of the fort and mound may have begun before Tongan invaders, possibly led by Tu'i Tonga Kau'ulufonua in the $15^{\text {th }}$ century (Sand, 2006). The influence of Tongan contact in early Western Polynesia is 
prominent, not only in Sāmoa but also Uvea. Sāmoa, Tonga, 'Uvea and Futuna demonstrate the primary centrality of West Polynesia, they are even described by some as the founding fathers of the Western region, over much smaller and break off isles such as Niue, New Caledonia, Tokelau and Tuvalu. Located north of Tonga, 'Uvea served as a stopover point for voyaging traffic between Sāmoa and Fiji and other island destinations. The long distances demonstrate the expansionist abilities and capabilities of the entrepreneurial Tongan empire during early West Polynesia (Sand, 2006). Aside from Talietumu and Kolonui, the number of mounds and platforms evident in 'Uvea, draws a close architectural relationship with Sāmoa and the numerous sites and mounds that share similar construction. (Sand, 2006).

The island of 'Uvea is an atoll island with a number of minor islets found throughout its archipelago. "Also known as "Ouvea" in New Caledonia, it was colonized by both Wallisians and the indigenous people of New Caledonia in the 13th Century. It is believed that Tongans also inhabited the western part of the island of 'Uvea and that they were known as "master carpenters" (Wakefield, 2015). Furthering local oratory and historical social intersection, Feinberg (1989) in his research on Tongan and Anutan prehistoric contact, reveals that the 'Uvean language draws strong influence from Tongan linguistics, upon the invading arrival of Tongans to 'Uvea (Feinberg, 1989). In addition to Tongan influence, Sand also tells of aspects regarding Wallisian ('Uvean) language, social and indigenous culture, as they are believed to be more Tongan, in comparison to Sāmoan, where it's believed they possess greater influence in Futuna (Sand, 2006). Former prime minister of Tonga, the honorable Baron 
Vaea explained in a scholastic documentary, that he was the original pioneer of the well known Tongan dance form, the Kailao. He believed he introduced the dance to Tonga from 'Uvea (BYU Hawaii film, 2000). Vaea describes his experience of being in the island of Ha'apai when he met a group of 'Uvean people. During a local festival, these 'Uveans performed a peculiar dance with locals including Vaea. In the birthday celebration of King Taufa'ahau Tupou IV, Vaea brought the 'Uvean group to teach their dance to the Tongan people. Years later, the dance became known as the Kailao, and has become an adopted and adapted performing art within traditional Tongan song and dance (BYU Hawaii film, 2000). Such stories and social interconnectivity support scholarship research on early and ongoing contact between Western Polynesian countries.

\section{Royal Burial Tombs of Tonga}

The central island of Tonga, known as Tongatapu, when translated, refers to the "Sacred South". Composed of four island groups being Niua, Vava'u, Ha'apai and Tongatapu, with the first mentioned three located in the northern areas of the archipelago moving towards Sāmoa. This Tongan archipelago is a mix of landform origins, including limestone islands, volcanic mid-plate and plate margin islands (Rapaport, 2013), with the centrality of Tongan chiefdom founded in Tongatapu going as far back as the $10^{\text {th }}$ century (Shutler, et al., 1994). In the eastern district of Hahake is the sub-district of Mu'a, sharing the same locative name as Talietumu/ Kolonui also located in an area named Mu'a. This sub-district of Mu'a has two coinciding villages being Lapaha and Tatakamotonga. The ancient Langi or royal tombs of the Tu'i Tonga empire 
are located in Lapaha, where the ancient capital of Tonga was once established. Lapaha, like Manu'a in Sāmoa, was a prominent place of political power, exchange and social affairs, until later eventually losing its overall dominion to other royal bloodlines namely the Tu'i Ha'atakalaua and later Tu'i Kanokupolu dynasties (Clark, et al.,2014). Regardless of overthrow, Lapaha specifically and historically still remains as the domain of the Tu'i Tonga, with royal ancestors who lay buried in stone tombs made from quarried slabs of beach rock and reef limestone weighing some 20 tons (Collocott, 1924).

"Radiocarbon dates, architectonic features, and chiefly genealogies indicate the first royal tombs were built 1300-1400AD, with the last constructed in $1760 \mathrm{AD}$. Additional constructions marking the chiefly center include ditch systems, roads, earth burial mounds, sitting platforms, bathing wells, standing stones, and a large area of reclaimed land containing a canoe harbor and wharf, which highlight the importance of maritime transport to the polity " (Clark, et al., 2014).

Overall in the area of Lapaha alone, 27 stone tombs are found, standing almost 4 meters high, each with details regarding their origin and production, with some stone burials having lithology originating in areas of Sāmoa, Uvea and Fiji. "Geochemical analysis of lithics from the Tongan state (Lapaha) on Tongatapu demonstrates that although the local volcanic sources from within the archipelago were used in tool production, around two thirds of all adzes-flakes came from other island group, particularly Samoa and Fiji." (Clark, et al., 2014).

This close association between lithology and royal lines also demonstrates the spatial relativity Tongans and 
Sāmoans share alongside Fijian chiefdoms, whether through martial means or other social formalities.

The stone tombs of Lapaha share an uncanny appearance similarly seen in both Sāmoa and Uvea, following a homogeneous structure of large flat rock slabs that appear almost laid over another presenting a possible form of stairs. In observation of other Tongan traditions, the practice of Ngatu (Barkcloth/ Tapa) displays a specific and compelling Kupesi (Indigenous designs and patterns) called "Fataotuitonga" or "Fata 'O Tu'i Tonga' which shares strong similarities in the structural shape of these Langi tombs (See fig. 1). This Kupesi follows a square outline with smaller squares placed within the initial square, numbering two to three times. Additionally, two lines are observed, each drawn diagonally from the top left corner to the bottom right and right to left. Artistic designs vary depending on artists. However, some prefer the design as an array of lines demonstrating a more simplistic motif, while others prefer more complex colored variations of the pattern (See figs. 2-4). "The highly skilled craftsmen, Ha'a Tufunga, built high precision monuments for the Tu'i Tonga chiefs at the height of their rein. Six different forms of tomb have been identified; although they vary in volume, area, height, materiality, architectural features and placement. Each site is chosen for its' view and breeze for when the chief's spirit sits atop to tomb, but it is uncertain why there is variation in the other components of the tombs" (To'a \& Sione, 2001) (See figs 5 and 6) "The tombs hold the bodies of the chief, his wife, and children; but also used to signify semi-divinity the chiefs had. The articulation of architecture symbolized hierarchy, divinity, and the connection to the three main aspects of 
Tongan culture through vertical and horizontal features. Burial connects to the underworld, Lolofonua, verticality connects to the sky, Langi, and horizontality connects to highest divinity, Pulotu. For commoners the process only involved the connection to the underworld by being buried" (To'a \& Sione, 2001). Returning back to the significance of the "Fata 'O Tu'i Tonga", when carefully evaluated it is suggested that this Kupesi is a possible artistic aerial view referring to the homeland, stronghold or domain of the Tu'i Tonga being that of the famous ancient stone tombs in Lapaha. The megalithic structures at Lapaha speak to an era when native inhabitants were at a pinnacle point in their existence, creating impacts on one another as kin and other Western Polynesians, beginning possibly right from inception. It highlights for Tongans [and Western Polynesians] the significance of Tā (time) and Vā (space) relationships to ancestors before and posterities that live on today (Enari \& Faleolo, 2020; Ka'ili, 2005). This paper thus far, has highlighted the numerous occasions of entrepreneurial, architectural and economical success of the Tu'i Tonga empire. That through varied means including the architectural genius of pre-colonial burials, it's legacy lives on within people and heritage and their relationship to history and land. 


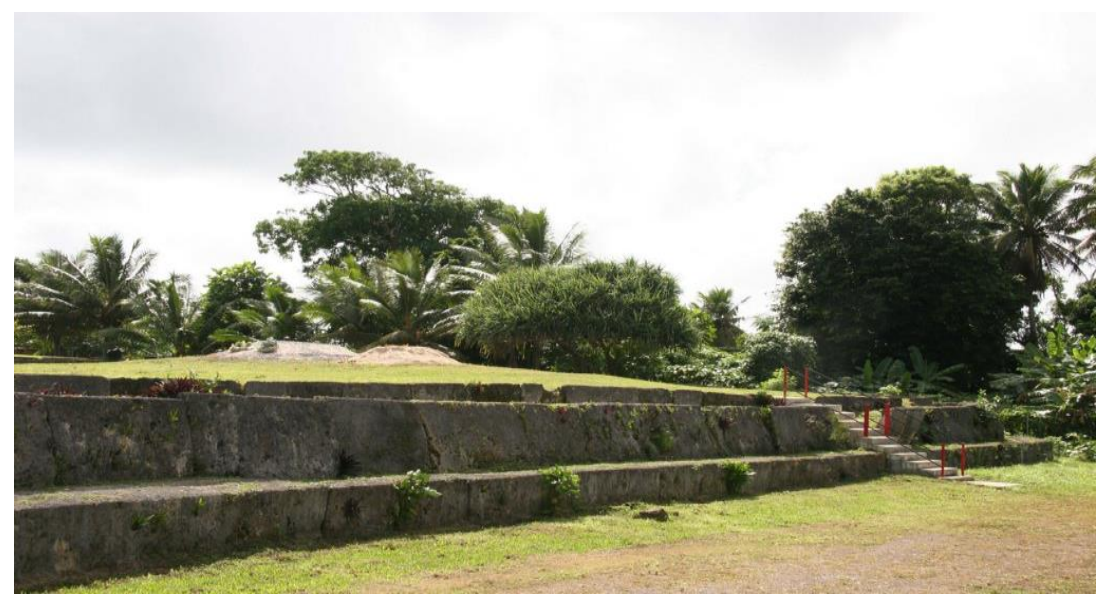

Figure 1: Example of Langi (Royal Burial Tombs) in Lapaha. (https://mapio.net/a/114566890/)
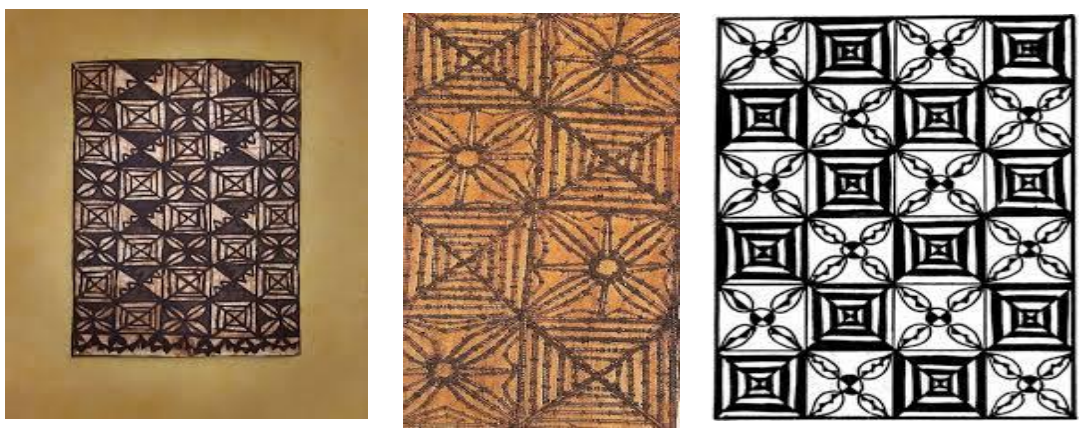

Figures 2-4: Example variations of Fata 'O Tu'i Tonga (Kapa Kulture, 2013) 


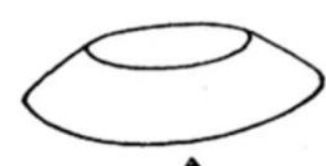

A

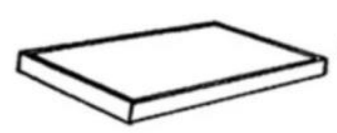

D

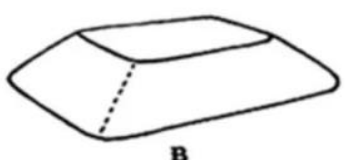

B

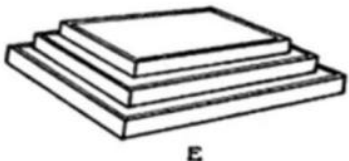

E
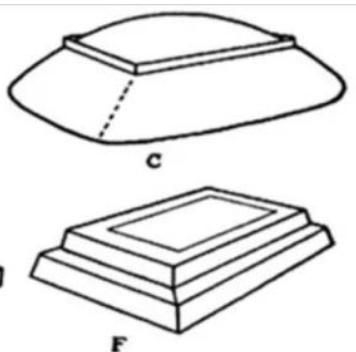

MaKeco 1929, pg 35.

Figure 5: Example of 6 different tomb formations. (To'a \& Sione, 2001)

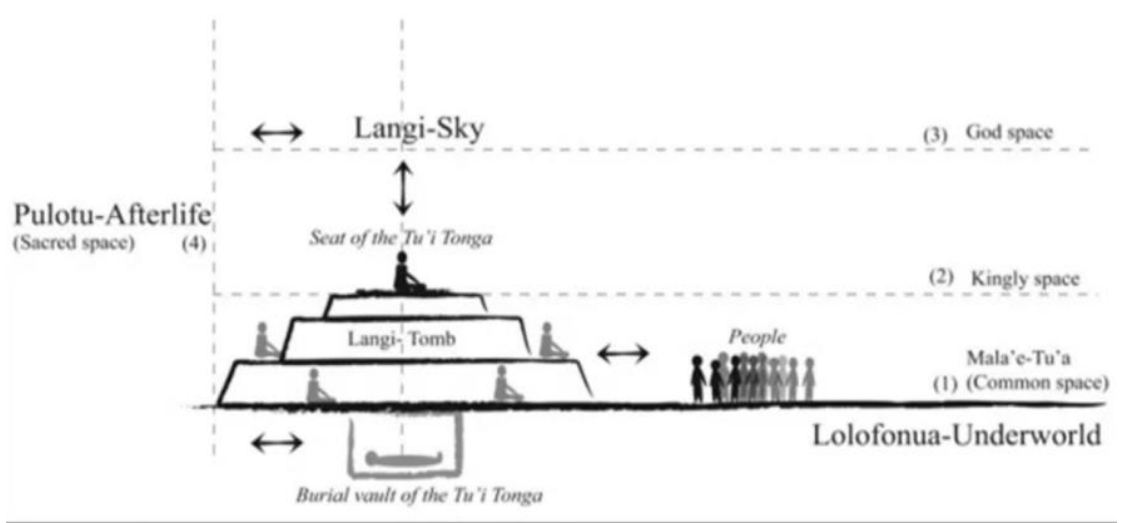

Jo'a Moa, Bruce Signe. "Langi Royal Tombs, the beginning of Tui Tonga architecture." Master's thesis, The University of Auckland, 2001.

Figure 6: Example of Langi social hierarchy articulation and functionality. (To'a \& Sione, 2001) 


\section{Conclusion}

"Most complex societies in the Pacific only developed in the past 1000 years and external drivers such as climate change have been proposed motivators to explain the widespread emergence of hierarchically stratified societies. However, the lithic networks indicate that stratification was accompanied by the development of significant interaction centers in the Central Pacific that had the capacity to transmit information about political organization to many parts of Oceania" (Clark, et al., 2014).

The structural remains of ancient West Polynesian monuments are still visible today and are a time-long testament to the pioneering efforts of early Sāmoans, Tongans, 'Uveans and other Western Polynesian groups in the early centuries of 1100-1600AD before the arrival of European-American colonialism. It further strengthens Epeli Hau'ofa's account in labelling the region as "vast, expanding, hospitable and generous, Oceania is humanity rising from the depths of brine and regions of fire deeper still, Oceania is us" (Hau'ofa, 1993).

The significant similarities in architectural construction, linguistics, social influence and contact, formal titles, geological materials, coherent time periods and geographic specificity of these structures and peoples, displays the extensive interconnectivity that is shared within the West regions of Polynesians. Through time Tā (time) and space Vā (space), early Polynesians defied colonial minds and limitations that were later said to be the downfall and weaknesses of their societies. Yet over time, these Polynesians still continue to defy those barriers of inter-migration and multi-dimensional identity (Enari \& Fa'aea, 2020; Fa'aea \& Enari, 2021). 
"The need to utilize the various traditional means of passing history orally from generation to generation, and the forthright expressions of deeply felt nationalistic, anti-colonial sentiments, are inevitable... Only we can live up to the ultimate goals of our professions" (Latukefu, 1992). The nourishment and perpetuation of indigenous knowledge through history, language, economics, agriculture, social interactions and geographic movements via the seen and unseen times and spaces of the indigenous world are vital to ones' educational development (Enari, 2021; Enari \& Rangiwai, 2021; Matapo \& Enari, 2021). Western Polynesia is home to an abundance of rich heritages from movements of legendary ancestors and great kings before them, with much still intact, tangible and strongly implemented. While Moanans through the diaspora embark on diverse endeavors for employment, migration, education and other ambitions, as well as to see monuments abroad and know of the unlimited wonders of the world, I would challenge Moana people to adventure into the chronicles of their ancestral pasts where truths and mysteries of civilizations and colonies. Indeed, only we can attain the goals pertaining to our own individual professions and as such, only we are able to tell and (re)tell the stories of our people, as descendents of the original storytellers. 


\section{References}

Aswani, S., \& Graves, M. (1998) The Tongan Maritime Expansion: A Case in the Evolutionary Ecology of Social Complexity. Asian Perspectives, 37(2), 135-164.

Barnes, S., \& Hunt, T. (2005) Samoa's pre-contact connections in Wester Polynesian and Beyond. The Journal of the Polynesian Society, 114(3), 227-266.

Bott, Elizabeth. (1982) Tongan Society at the Time of Captain Cooks Visit: Discussions with her Majesty Queen Sālote Tupou. Published: Wellington: Polynesian Society, 1982. Memoirs of the Polynesian Society; no. 44.

Burley, D. (1996) Sport, Status, and Field Monuments in the Polynesian Chiefdom of Tonga: The Pigeon Snaring Mounds of Northern Ha'apai. Journal of Field Archaeology, 23(4), 421- 435. doi:10.2307/530546

BYU Hawaii, (2000) Haka He Langi Kuo Tau: We Dance in the Ecstasy of Singing. Tongan National Government. Consultant/Film Crew: Ethnographic Film.

Chao, S \& Enari, D (2021) Decolonizing Climate Change: A Call for Beyond-Human Imaginaries and Knowledge Generation. eTropic: electronic journal of studies in the tropics (Forthcoming)

Clark, G., \& Martinsson-Wallin, H. (2007) Monumental Architecture in West Polynesia: Origins, Chiefs and Archaeological Approaches. Archaeology in Oceania, 42, 28-40.

Clark GR, Reepmeyer C, Melekiola N, et al. (2014) Stone tools from the ancient Tongan state reveal prehistoric interaction centers in the Central Pacific. Proceedings of the National Academy of Sciences of the United States of America. Jul;111(29):10491-10496.

DOI: $10.1073 /$ pnas. 1406165111 
Collocott, E. (1924) An experiment in Tongan History. The Journal of the Polynesian Society, 33(3(131)), 166-184.

Cummins, H. (1975) Missionary Politicians. The Journal of Pacific History, 10(2), 105- 112.

Davidson, J. (1998) The Journal of the Polynesian Society, 107(2), 199-200.

Enari, D. (2021) Methodology marriage: Merging Western and Pacific research design.Pacific Dynamics: Journal of interdisciplinary research. https://ir.canterbury.ac.nz/bitstream/handle/10092/1 01590/5\%20Methodology.pdf?sequence $=5$

Enari, D. \& Matapo, J. (2020) The Digital Vā: Pasifika education innovation during the Covid-19 pandemic. MAI Journal, 9(4), 7-

11 http://www.journal.mai.ac.nz/sites/default/files/MA I_Jrnl_2020_V9_4_Enari_02.pdf

Enari, D. \& Matapo, J. (2021) Negotiating the relational vā in the University: A transnational Pasifika standpoint during the Covid-19 pandemic. Journal of Global Indigeneity.

https://www.journalofglobalindigeneity.com/article/19 436-navigating-the-digital-va-va-centring-moanapacific-values-in-online-tertiary-settings-during-covid$\underline{19}$

Enari, D., \& Fa'aea, A. M. (2020) E tumau le fa'avae ae fesuia'i faiga: Pasifika Resilience During COVID-19. Oceania, 90, 75-80.

https://onlinelibrary.wiley.com/doi/full/10.1002/ocea. $\underline{5269}$

Enari, D. \& Faleolo, R. (2020) Pasifika well-being during the COVID-19 crisis: Samoans and Tongans in Brisbane. Journal of Indigenous Social Development, 110-127. 
https://journalhosting.ucalgary.ca/index.php/jisd/arti cle/view/70734/54415

Enari, D \& Rangiwai, B (2021) Digital innovation and funeral practices: Māori and Samoan perspectives during the COVID-19 pandemic. Alternative journal (Forthcoming)

Fa'aea, A. M. \& Enari, D (2021) The pathway to leadership is through service: Exploring the Samoan tautua lifecycle. Pacific Dynamics: Journal of interdisciplinary research. https://ir.canterbury.ac.nz/bitstream/handle/10092/1 01592/7\%20Tautua-final.pdf?sequence $=5 \&$ is Allowed $=y$

Faka'osi, S. (1993) Land Tenure System: Changes and Constraints in Tongan Society. Department of Sociology: Faculty of Arts. The Australian National University Feinberg, R. (1989). Possible prehistoric contacts between Tonga and Anuta. The Journal of the Polynesian Society, 98(3), 303-317.

Geraghty, P., (1994) "Language Contact and Change in the Austronesian World: pp.236- 39

Gunson, N. (1997) Great Families of Polynesia: Inter-Island Links and Marriage Patterns. The Journal of Pacific History, 32(2), 139-179.

Gunson, N. (1987) Sacred Women Chiefs and Female 'Headmen' in Polynesian History. The Journal of Pacific History, 22(3), 139-172.

Hau'ofa, E. (1994) Our Sea of Islands. The Contemporary Pacific, 6(1), 148-161.

Herdrich, D. (1991) Towards an understanding of Samoan Star mounds. The Journal of the Polynesian Society, 100(4), 381-435.

Kaeppler, A.L. (1978) Exchange patterns in goods and spouses:

Fiji, Tonga, and Samoa. Mankind, 11:246-52. 
Ka'ili, T. (2005) Tauhi vā: Nurturing Tongan Sociospatial Ties in Maui and Beyond. The Contemporary Pacific, 17(1), 83114.

Ka'ili, T. and Okusitino M. (2017) Marking Indigeneity: The Tongan Art of Sociospatial Relations. University of Arizona Press.

Kapa kulture. (2021). Retrieved 20 April 2021, from https://kapakulture.com/

Lātūkefu, S. (1992) 'The Making of the First Tongan-born Professional Historian.' In Pacific Islands History: Journeys and Transformations, edited by Brij Lal, 14-31.

Canberra: The Journal of Pacific History.

Lemusuifeauaali'i, E \& Enari, D. (2021) DUA TANI: (Re)evolving Identities of Pacific Islanders. Te Kaharoa, 17(1). https://doi.org/10.24135/tekaharoa.v17i1.342

Māhina, 'Ō. (1992) "The Tongan Traditional History Tala-EFonua: A Vernacular Ecology-centered HistoricalCultural Concept", Unpublished PhD thesis, The Australian National University, Canberra.

Radakovich, J. (2004) Movement Characteristics of Three Samoan Dance Types: Mā'ulu'ulu, Sāsā and Taualuga. University of Hawai'i.

Matapo, J \& Enari, D (2021) Re-imagining the dialogic spaces of talanoa through Samoan onto-epistemology. In Waikato Journal of education. (Forthcoming)

Rapaport, M. (2013) The Pacific Islands: Environment and Society, Revised Edition. University of Hawai'i Press. Rottman, G (2002) World War Ii Pacific Island Guide: A Geo-Military Study. Westport, Conn: Greenwood Press.

Sand, C. (2006) "A View from the West: Samoa in the Culture History of 'Uvea (Wallis) and Futuna (Western Polynesia)". The Journal of Sāmoa Studies. 2: 5-15 
Shutler, R., Burley, D., Dickinson, W., Nelson, E., \& Carlson, A. (1994) Early Lapita Sites, the Colonisation of Tonga and Recent Data from Northern Ha'apai. Archaeology in Oceania, 29(2), 53-68.

Moa, T. \& Sione, B. (2001) "Langi Royal Tombs: the beginning of Tu'i Tonga architecture." Master's thesis, The University of Auckland, 2001.

Tuimalealiifano, Morgan. (2006) O Tama A 'Aiga: the politics of succession to Samoa's paramount titles. The Institute of Pacific Studies, the University of the South Pacific, Suva, Fiji. ISBN 9789820203778

Wallin, H; Clark, G; Wallin, P (2003) "Archaeological Investigations at the Pulemelei Mound".

Wallin, P., Martinsson-Wallin, H., \& Clark, G. (2007) A Radiocarbon Sequence for Samoan Prehistory and the Pulemelei Mound. Archaeology in Oceania, 42, 71-82.

\section{Image Sources}

Alluring World. (2021) Talietumu. Alluring World: Discover, Experience, Live.

http://www.alluringworld.com/talietumu/

Code, B., Cavanagh, Emily. (2020) A Secret Pyramid Consumed by Jungle. British Broadcasting Corporation (BBC). http://www.bbc.com/travel/story/20200109-a-secret pyramid-consumed-by-the-jungle

Coconet TV. (2019). Samoa's Ancient Star Mounds. https://www.thecoconet.tv/know-your-roots/pacifichistory-legends/samoas-ancient-star mounds/

Kapa Kulture. (2013) https://kapakulture.com/ Mapio.net. (2020) Langi (Ancient Burial Tombs), Tongatapu, Tonga. https://mapio.net/pic/p-17185835/

Rozario, Flame. (2020) Ancient Pyramids in Samoa and 80 Star Mounds Revealed with LIDAR. Crypto Anthropologist. 
https://www.cryptoanthropologist.com/2020/08/ancie nt-pyramids-in-samoa-and-80-star.html

To'a Moa, Bruce Sione. (2001) "Langi Royal Tombs: the beginning of Tu'i Tonga architecture." Master's thesis, The University of Auckland, 2001. 